\title{
"Indicators of product quality: faith labels as branding tools"
}

\begin{tabular}{|c|c|c|}
\hline AUTHORS & $\begin{array}{l}\text { Dana-Nicoleta Lascu D https://c } \\
\text { R http://www.researcherid.com } \\
\text { Christopher Cotter } \\
\text { Mari Sato } \\
\text { Timothy Wing }\end{array}$ & $1-5071-3349$ \\
\hline ARTICLE INFO & $\begin{array}{l}\text { Dana-Nicoleta Lascu, Christoph } \\
\text { Indicators of product quality: fait } \\
\text { 12(2), 28-31. doi:10.21511/im.1 }\end{array}$ & $\begin{array}{l}0 \text { and Timothy Wing (2016). } \\
\text { g tools. Innovative Marketing, }\end{array}$ \\
\hline DOI & http://dx.doi.org/10.21511/im.12 & \\
\hline RELEASED ON & Wednesday, 14 September 201 & \\
\hline JOURNAL & "Innovative Marketing " & \\
\hline FOUNDER & LLC "Consulting Publishing Cor & Perspectives" \\
\hline 0 & $D$ & $\begin{array}{l}\text { 三: } \\
\text { 三: }\end{array}$ \\
\hline NUMBER OF REFERENCES & NUMBER OF FIGURES & NUMBER OF TABLES \\
\hline 0 & 0 & 0 \\
\hline
\end{tabular}

(c) The author(s) 2022. This publication is an open access article. 


\title{
Dana-Nicoleta Lascu (USA), Christopher Cotter (USA), Mari Sato (USA), Timothy Wing (USA) Indicators of product quality: faith labels as branding tools
}

\begin{abstract}
Halal and kosher foods are a growing sector in the food processing industry (Maddock, 2014). While halal and kosher labels primarily target Muslim and Jewish consumers adhering to laws that govern the production of "pure, safe, acceptable foods, consumers who do not follow either religion are increasingly showing a preference for foods with a halal or kosher label" (Maddock, 2014). This study attempts to assess whether consumers in the United States who do not follow either religion may perceive halal or kosher labels to signal a higher quality product. The study explores consumers' understanding of the halal and kosher process, and attempts to identify the determinants of their assessments.
\end{abstract}

Keywords: faith branding, kosher, halal, Islamic law, Jewish law, food marketing.

JEL Classification: M31, K00.

\section{Introduction}

Practitioner research suggests that Muslim consumers are willing to pay a premium for halal and Jewish consumers are willing to pay a premium for kosher foods (Maddock, 2014). It is suggested that even in countries where Muslims or Jews are minorities, non-Muslim and nonJewish consumers may consider products with a halal or kosher designation as indicative of quality (Maddock, 2014), and, thus, develop preferences for such products. Based on these findings, a study was conducted in the United States, a country with a history of adopting into the mainstream traditions from its ethnic and religious subcultures (Hine, Hine and Harold 2006) and with large Muslim and Jewish subcultures. The Muslim population in the United States is estimated at 3.3 million, or .9 percent of the U.S. population (Mohammed, 2016), whereas the Jewish population is 4.2 million, or 1.8 percent of the U.S. population (Pew Research Center, 2016).

\section{Rules for religious consumption}

Halal laws are derived from the Quran and the Hadith, the traditions of the prophet Mohammed. Food that is forbidden includes pork, blood, meat of animals that died of causes other than proper slaughtering, food that has been dedicated to someone other than Allah, alcohol, intoxicants, and inappropriately used drugs (Regenstein, Chaudry and Regenstein, 2003). The kosher dietary laws are derived from the Torah and the

(C) Dana-Nicoleta Lascu, Christopher Cotter, Mari Sato, Timothy Wing, 2016.

Dana-Nicoleta Lascu, Dr., School of Business, University of Richmond, USA.

Christopher Cotter, School of Business, University of Richmond, USA.

Mari Sato, School of Business, University of Richmond, USA.

Timothy Wing, School of Business, University of Richmond, USA. oral law received by Moses on Mount Sinai, the Talmud (Regenstein, Chaudry and Regenstein, 2003). Kosher meats include ruminants with split hoofs that chew their cud, traditional domestic birds, and fish with fins and removable scales are permitted. Pigs, wild birds, sharks, dogfish, catfish, monkfish, and similar species are prohibited, as are all shellfish and insects.

Both religions have a zero tolerance for the consumption of pork and will consider processing equipment used to produce pork products as unsuitable, even with cleaning and sanitizing (Maddock, 2014). Both have a prohibition of blood - the fresh product has to be soaked in water and covered in salt to draw out the remaining blood, which should be mostly removed in the slaughtering process (Maddock, 2014). Kosher also requires that meat and dairy products not be mixed, so equipment used to process dairy products needs to be cleaned and sanitized before producing meat products. Also, the area of the carcass that contains the sciatic nerve (the hind quarter) is not kosher, which means finding alternative, non-kosher markets for this meat (Maddock, 2014).

Differences between halal and kosher include food processing: kosher slaughter requires a trained rabbi, whereas halal slaughter does not require a trained religious leader. Both halal and kosher meat products need a third-party certification and inspection that will allow producers to have a halal or kosher label. The costs of certification and inspection and the previously mentioned additional costs involved in the production of halal and kosher meats must be offset by higher prices. Prices for kosher raw products are typically 20-30 percent higher than for conventional products, whereas prices of halal raw products are thought to be as much as double for some meat products (Maddock, 2014). 


\section{Halal and kosher adoption by non-Mulsims and non-Jews: hypotheses}

Studies found that price and brand name are important determinants of product quality perceptions (Monroe and Krishan, 1985; Garvin, 1987; Brooks and Zeithaml, 1991), but, upon further examination, research suggests that consumers do not perceive quality as an overall global evaluation, but, instead, as composed of several factors.

Instead of overall quality, dimensions of quality form a better basis for understanding the important relationships involved in consumer judgment and choice; among these dimensions are ease of use, versatility, durability, serviceability, performance, and prestige (Brooks, Zeithaml and Naylor, 2000).

For food products, it has been determined that quality and safety perception is linked to food choice and consumer demand: food quality and safety are central issues in today's food economics (Grunert, 2005). Specifically, consumers are giving increasing importance to quality attributes in response to rising concerns about safety, health, ethical factors, as well environmentally-friendly production and respect for the animal welfare (Bernues, Olaizola and Corcoran, 2003). We argue that proper slaughtering and processing, as mandated by halal and kosher requirements, address, from the consumers' perspective, the safety and health attributes that are likely indicators of product quality that consumers will likely spend more to obtain. It is thus, probable that familiarity with halal or kosher will lead individuals to spend more on halal or kosher products, respectively. It is also likely that familiarity with halal or kosher processing will enhance individuals' assessment of the good as fresher, given the strict requirements for meat slaughtering and processing, and healthier. We, thus, hypothesize that:

H1: Familiarity with halal will lead individuals to spend more on halal goods.

H2: Familiarity with kosher will lead individuals to spend more on kosher goods.

H3: Familiarity with halal will lead individuals to perceive halal goods as fresher and healthier.

H4: Familiarity with kosher will lead individuals to perceive kosher goods as fresher and healthier.

In the next section, the research method, analyses, and results are presented in an effort to determine the extent of knowledge non-Muslim and nonJewish consumers have of halal and kosher processes, and to identify the extent to which their knowledge might influence their perception of product freshness and healthfulness, as well as the likelihood that they would spend more on products with the halal or kosher label.

\section{Research method and results}

A survey using a snowball judgment sample of Millennial and Generation- $Z$ respondents in the United States was used to assess consumers' perception of the health aspects of halal and kosher meat products. Using semantic differential scales, the data collection instrument assessed respondents' familiarity with halal or kosher, the likelihood that they would spend more on either, and their perceptions that halal or kosher were healthier or fresher.

A total of 69 respondents filled out the questionnaire. First, the respondents who selfidentified as Jewish and Muslim were eliminated from the sample, as the goal was to assess the perceptions of individuals who didn't adhere to either religion. Four of the respondents indicated that they were either Jewish or Muslim, and were eliminated from the study, leaving a total of 65 respondents, a number deemed sufficient for the intended analyses. A total of 77 percent of respondents ranged in age between 18 and 23, most of the respondents were female - 75.4 percent, - and 78.5 percent had some college/were in college, while the remaining respondents had either a bachelor's or graduate degrees.

It was found that individuals familiar with halal were significantly more likely to spend more on halal $(\mathrm{r}=.41 ; \mathrm{p}<.01)$, thus, providing support for hypothesis H1. Similarly, individuals familiar with kosher were more likely to spend more on kosher, supporting hypothesis $\mathrm{H} 2$; however, this finding was only marginally significant $(r=.23$; $\mathrm{p}<.10)$. Interestingly, and not hypothesized herein, it was found that individuals who were familiar with halal were also likely to be familiar with kosher $(\mathrm{r}=.25 ; \mathrm{p}<.05)$. In fact, individuals familiar with halal were more likely to spend more on kosher as well $(\mathrm{r}=.27 ; \mathrm{p}<.05)-$ individuals familiar with kosher were not likely to spend more on halal $(\mathrm{r}=.17 ; \mathrm{p}>.10)$. Finally, and noteworthy as well, individuals likely to spend more on halal were also likely to spend more on kosher $(r=.69 ; p<.01)$. See Table 1 . 
Table 1. Familiarity and willingness to spend on halal and kosher - correlations

\begin{tabular}{|l|c|c|c|c|}
\hline & $\begin{array}{c}\text { Familiar with } \\
\text { halal }\end{array}$ & $\begin{array}{c}\text { Familiar with } \\
\text { kosher }\end{array}$ & $\begin{array}{c}\text { Spend more } \\
\text { on halal }\end{array}$ & $\begin{array}{c}\text { Spend more } \\
\text { on kosher }\end{array}$ \\
\hline $\begin{array}{l}\text { Familiar with } \\
\text { halal }\end{array}$ & 1 & 1 & & \\
\hline $\begin{array}{l}\text { Familiar with } \\
\text { kosher }\end{array}$ & $\begin{array}{c}r=.25 \\
(p<.05)\end{array}$ & 1 & \\
\hline $\begin{array}{l}\text { Spend more } \\
\text { on halal }\end{array}$ & $\begin{array}{c}r=.41 \\
(p<.01)\end{array}$ & $\begin{array}{c}r=.17 \\
(p>.10)\end{array}$ & 1 & \\
\hline $\begin{array}{l}\text { Spend more } \\
\text { on kosher }\end{array}$ & $\begin{array}{c}r=.27 \\
(p<.05)\end{array}$ & $\begin{array}{c}r=.23 \\
(p<.10)\end{array}$ & $\begin{array}{c}r=.69 \\
(p<.01)\end{array}$ & 1 \\
\hline
\end{tabular}

Familiarity with halal or kosher did not correlate with the perception that either is healthier or fresher than meat products that did not have the designation (see Table 2), and, thus, did not provide support for hypotheses $\mathrm{H} 3$ and $\mathrm{H} 4$. On the other hand, again, noteworthy relationships were found between those who perceived halal as healthier and fresher and those who perceived kosher as healthier and fresher. As expected, those who perceived halal or kosher as healthier also perceived it as fresher, respectively. Specifically, those who perceived halal as fresher also perceived it as healthier $(r=.86 ; p<.01)$ and, interestingly, they also perceived kosher as fresher $(\mathrm{r}=.81 ; \mathrm{p}<.01)$ and healthier $(\mathrm{r}=.80 ; \mathrm{p}<.01)$. Similarly, those who perceived halal as healthier, also perceived kosher as fresher $(\mathrm{r}=.79 ; \mathrm{p}<.01)$ and healthier $(r=.80 ; p<.01)$. Finally, those who perceived kosher as fresher also perceived it as healthier $(\mathrm{r}=.77 ; \mathrm{p}<.01)$. See Table 2 .

Table 2. Familiarity and expenditures on halal and kosher - correlations

\begin{tabular}{|c|c|c|c|c|c|c|}
\hline & Familiar with halal & Familiar with kosher & Halal is fresher & Halal is healthier & Kosher is fresher & Kosher is healthier \\
\hline Familiar with halal & 1 & & & & & \\
\hline Familiar with kosher & $\begin{array}{c}r=.25 \\
(p<.05)\end{array}$ & 1 & & & & \\
\hline Halal is fresher & $\begin{array}{c}r=.19 \\
(p>.10)\end{array}$ & $\begin{array}{c}r=.13 \\
(p>.10)\end{array}$ & 1 & & & \\
\hline Halal is healthier & $\begin{array}{c}r=.13 \\
(p>.10)\end{array}$ & $\begin{array}{c}r=.15 \\
(p<.10)\end{array}$ & $\begin{array}{c}r=.86 \\
(p<.01)\end{array}$ & 1 & & \\
\hline Kosher is fresher & $\begin{array}{c}r=.41 \\
(p<.01)\end{array}$ & $\begin{array}{c}r=.17 \\
(p<.10)\end{array}$ & $\begin{array}{c}r=.81 \\
(p<.01)\end{array}$ & $\begin{array}{c}r=.79 \\
(p<.01)\end{array}$ & 1 & \\
\hline Kosher is healthier & $\begin{array}{c}r=.27 \\
(p<.05)\end{array}$ & $\begin{array}{c}r=.23 \\
(p<.10)\end{array}$ & $\begin{aligned} r & =.80 \\
(p & <.01)\end{aligned}$ & $\begin{array}{c}r=.80 \\
(p<.01)\end{array}$ & $\begin{array}{c}r=.77 \\
(p<.01)\end{array}$ & 1 \\
\hline
\end{tabular}

\section{Discussion and conclusions}

The analyses found that familiarity with halal and kosher created a greater likelihood that individuals would be willing to pay more for the respective offerings. However, this was not because they perceived either as being healthier or fresher. We posit that this because of the perception that ritual killing is more humane. Halal slaughter implies respect for the animal, and it is performed as humanely as possible, without torturing the animal (ADCM.org, 2016). Similarly, kosher is interpreted as being pure, and kosher slaughter is considered to be "the opposite of the industrialization of slaughter" (Rosenberg, 2016). However, much research on the topic suggests that not stunning the animal prior to slaughter is cruel, and countries such as the Baltics, Denmark, Norway, Poland, Sweden, and Switzerland, among others, have outlawed ritual slaughter (Rosenberg, 2016; ADCM.org, 2016).

In the study findings, the crossover effects between halal and kosher were noteworthy, with individuals familiar with one also familiar with the other, and with individuals who perceived one as healthier or fresher also very likely to perceive the other as healthier or fresher.

From the point of view of marketing halal and kosher products to non-Muslim and non-Jewish consumers, it is advisable to target either faith label to the same consumers, who would be willing to pay more for halal or kosher. These are those consumers who are familiar with halal and kosher designations - most likely, individuals living in larger cities with a strong multicultural presence and who are exposed to halal and kosher offerings. While the study did not identify the respondents by place, it would be interesting for a follow-up study to examine if familiarity with halal and kosher is greater in large metropolitan areas and if those consumers are more inclined to pay more for faith labels.

Those individuals who are already sold on either halal or kosher as being fresher or healthier are likely to perceive the alternative faith offering, kosher or halal, respectively, as healthier and fresher. This study did not assess purchase intentions - although a future study might explore this aspect; however, it would not be a leap to assume that individuals who perceive a product to be healthier and fresher might purchase the respective product. The segment that believes that the two faith labels are healthier and fresher than non-faith labels is more difficult to identify. But, here, again, it is likely that individuals who have some exposure to the respective cultures - although, as the study indicates, not a high familiarity with either - are more likely to assess the offerings as being healthier and fresher. These individuals, again, are likely to live in urban areas where both 
the Muslim and the Jewish subcultures are represented.

Future studies may explore attitudes within the Muslim and the Jewish subcultures, respectively, and offer similar insights and comparisons on the extent to which faith-branded goods are perceived as healthier or fresher, and on whether individuals are willing to pay more to obtain the products. It would be particularly interesting to assess the extent to which Muslims are willing to consume kosher goods and Jews are willing to consume halal goods. The present study assessed the opinions of primarily Millennials and Generation- $Z$ consumers; it would be interesting to be able to compare their attitudes with those of a larger sample of older consumers.

\section{References}

1. ADCM.org. (2016) Le Respect de l'Animal. Available at: http://www.adcm.org/dossiers/95-le-respect-de-lanimal. Accessed on August 10, 2016.

2. Bernues, Alberto, Olaizola, Ana, and Corcoran, Kate (2003). Extrinsic attributes of red meat as indicators of quality in Europe: an application for market segmentation, Food Quality and Preference, 14 (4), pp. 265-276.

3. Brooks, Merrie and Zeithaml, Valarie (1991). Price and Brand Name as Indicators of Quality Dimensions, MSI Institute, pp. 91-130.

4. Naylor, Gillian (2000). Price and Brand Name As Indicators of Quality Dimensions for Consumer Durables, Journal of the Academy of Marketing Science, 28, pp. 359-374.

5. Garvin, David A. (1987). Competing on the Eight Dimensions of Quality, Harvard Business Review, 65 (November-December), pp. 101-109.

6. Grunert, Klaus G. (2005). Food quality and safety: consumer perception and demand, European Review of Agricultural Economics, 32 (3), pp. 369-391.

7. Hine, Darlene, Hine, William C., and Harrold, Stanley (2006). The African American Odyssey. Boston, MA: Pearson.

8. Maddock, Rober (2016). Three consequences of the growth of kosher and halal meats, Meatingplace, February 10 , 2014. Available at: www.meatingplace.com/Industry/TechnicalArticles/Details/46223. Accessed on February 15, 2016.

9. Basheer, Mohammed (2016). A new estimate of the U.S. Muslim population, Pew Research Center, January 6, 2016. Available at: http://www.pewresearch.org/fact-tank/2016/01/06/a-new-estimate-of-the-u-s-muslimpopulation. Accessed on February 1, 2016.

10. Monroe, Kent, B. and Krishnan, R. (1985). The Effect of Price on Subjec-tive Product Evaluations. In Perceived Quality. Eds. J. Jacoby and J. Olson. Lexington, MA: Lexington Books, pp. 209-232.

11. Pew Research Center, A Portrait of Jewish Americans, October 1, 2013. Available at: http://www.pewforum.org/2013/10/01/chapter-1-population-estimates on February 1, 2016.

12. Rosenberg, Martha (2016). Is Kosher Slaughter More Humane? Food Consumer, July 29. Available at: http://www.foodconsumer.org/newsite/Politics/Politics/is_kosher_slaughter_more_humane_0728160947.html.

Accessed on August 10, 2016. 